\title{
Photocatalytic degradation of tetracycline using nanosized titanium dioxide in aqueous solution
}

\author{
G. H. Safari $\cdot$ M. Hoseini $\cdot$ M. Seyedsalehi $\cdot$ \\ H. Kamani · J. Jaafari $\cdot$ A. H. Mahvi
}

Received: 6 January 2014/Revised: 7 October 2014/Accepted: 27 October 2014/Published online: 15 November 2014

(C) Islamic Azad University (IAU) 2014

\begin{abstract}
The aim of the study was to investigate the degradation kinetics of tetracycline antibiotic by nanosized titanium dioxide under ultraviolet irradiation. Enhancement of photocatalysis by addition of Hydrogen peroxide was also evaluated. Various experimental parameters such as initial tetracycline concentrations, initial titanium dioxide concentration, initial $\mathrm{pH}$, reaction times, initial Hydrogen peroxide concentrations, as well as water matrix using ultrapure water, drinking water and secondary effluent were investigated. The initial rate of photocatalytic degradation of tetracycline well fitted the Langmuir-Hinshelwood kinetic model $\left(R^{2}=0.9926\right)$ with a reaction rate constant of $1.4 \mathrm{mg} / \mathrm{L} \mathrm{min}$. The
\end{abstract}

G. H. Safari · M. Hoseini · H. Kamani · J. Jaafari ·

A. H. Mahvi ( $\square)$

School of Public Health, Tehran University of Medical Sciences,

Tehran, Iran

e-mail: ahmahvi@yahoo.com

M. Hoseini

Department of Environmental Health Engineering, School of

Health, Shiraz University of Medical Sciences, Shiraz, Iran

\section{Seyedsalehi}

Department of Environmental Engineering, Science and

Research Branch, Islamic Azad University, Tehran, Iran

H. Kamani

Health Promotion Research Center and School of Public Health,

Zahedan University of Medical Sciences, Zahedan, Iran

\section{A. H. Mahvi}

Centers for Solid Waste Research, Institute for Environmental Research, Tehran University of Medical Sciences, Tehran, Iran

A. H. Mahvi

National Institute of Health Research, Tehran University of Medical Sciences, Tehran, Iran degradation rate depended on initial tetracycline concentration and initial $\mathrm{pH}$. The degradation rate also increased with higher titanium dioxide density and reached a plateau at titanium dioxide concentration of $1.0 \mathrm{~g} / \mathrm{L}$. The tetracycline degradation rate was higher in drinking water compared to ultrapure water. The addition of Hydrogen peroxide to titanium dioxide suspension significantly enhanced the tetracycline degradation rate and substantially reduced the time required to degrade $100 \%$ of tetracycline. Changes of chemical oxygen demand values during photolysis indicated that tetracycline transformed into intermediate products without complete mineralization. The ultraviolet visible spectra obtained before and after ultraviolet irradiation in the presence of titanium dioxide can indicate the formation of $4 \mathrm{a}, 12 \mathrm{a}$-anhydro-4oxo-4- dimethylaminotetracycline.

Keywords Advanced oxidation process - Hydrogen peroxide $\cdot$ Kinetics $\cdot$ Photocatalysis $\cdot$ Ultraviolet radiation

\section{Introduction}

Over the past few years, antibiotics and their metabolites have been detected in surface water, ground water, wastewater, and drinking water at levels ranged from ng/ $\mathrm{L}$ to $\mu \mathrm{g} / \mathrm{L}$ (Kim and Tanaka 2009; Lopez-Penalver et al. 2010). For instance, residual concentrations of antibiotics have been detected up to $6,000 \mathrm{ng} / \mathrm{L}$ in sewage treatment plant effluent, up to $1900 \mathrm{ng} / \mathrm{L}$ in surface water and up to $470 \mathrm{ng} / \mathrm{L}$ in ground water. The highest concentration of antibiotics detected in the aquatic environments is $28,000-31,000 \mu \mathrm{g} / \mathrm{L}$. This was found in the effluent of a wastewater treatment plant that serves 90 pharmaceutical plants (Kummerer 2009). The 
introduction of antibiotics residual into environment through various sources can lead to serious environmental problems including ecological and human health damages (Daghrir and Drogui 2013). Tetracyclines (TCs) are a large group of antibiotics with widespread use in human and veterinary medicine and account for approximately $29 \%$ of total antibiotic use (Wammer et al. 2011). After medication, more than $70 \%$ of TC antibiotics were released in active form into the environment (Daghrir and Drogui 2013). In recent years, the presence of TC in surface water and even in ground water has been also reported (Liu et al. 2012). For example, up to $20 \mathrm{mg} / \mathrm{L}$ of TC was detected in manure, and half of the 139 rivers surveyed in the USA had detection of antibiotics (Chang et al. 2014). The average concentration of TC, oxytetracycline (OTC), and chlortetracycline (CTC) reported in US surface water were $0.11,1.34$, and $0.15 \mu \mathrm{g} / \mathrm{L}$, respectively (Lindsey et al. 2011). In addition, they have relatively long half-life, up to 180 days, depending on environmental conditions (Jiang et al. 2014). Most conventional wastewater treatment plants are inefficient in the removal of TC antibiotic (Homem and Santos 2011; Daghrir and Drogui 2013). Therefore, the development of new efficient approaches is required to decrease the TC antibiotic discharge into the environment. In general, advanced oxidation processes (AOPs) are the most efficient technology for degradation of various refractory pollutants in aqueous solutions and, during the last few decades, have been widely applied for removal of many organic pollutants such as ozonation (Khan et al. 2010), Fenton (Zgajnar Gotvajn et al. 2013), photo-Fenton (Liu et al. 2012), ultrasound waves (Mahvi 2009; Mahvi et al. 2009), sonochemical (Ifelebuegu et al. 2014), photosonochemical processes (Mahvi and Maleki 2010; Hoseini et al. 2013b), ultraviolet irradiation (Dobaradaran et al. 2010), and sulfate radical-based oxidation (Tay et al. 2013; Lin et al. 2014; Deng et al. 2014). In recent years, AOPs have been demonstrated to be an effective technology for the removal of pharmaceuticals, including TC antibiotics (Maroga et al. 2012). Among different AOPs, titanium dioxide $\left(\mathrm{TiO}_{2}\right)$ photocatalytic process is one of the most promising and emerging technology. $\mathrm{TiO}_{2}$ photocatalytic process seems to have key advantages, such as operation at ambient conditions and lack of mass transfer limitations. The mechanism of this process includes the activation of a semiconductor (usually an inorganic semiconductor, such as $\mathrm{TiO}_{2}$ ) via artificial light or sunlight (Homem and Santos 2011).

The objective of the present study was to evaluate the kinetics of TC degradation by UV irradiation, $\mathrm{UV} / \mathrm{TiO}_{2}$ and $\mathrm{UV} / \mathrm{TiO}_{2} / \mathrm{H}_{2} \mathrm{O}_{2}$ processes. Various experimental parameters such as initial TC concentration, initial $\mathrm{TiO}_{2}$ concentration, initial $\mathrm{pH}$, reaction time, initial $\mathrm{H}_{2} \mathrm{O}_{2}$ concentration as well as water matrix using ultrapure water, drinking water and secondary effluent were investigated. This study was performed at Department of Environmental Health Engineering, School of Public Health, Tehran University of Medical Sciences in 2013.

\section{Materials and methods}

\section{Chemicals}

Tetracycline hydrochloride $\left(\mathrm{C}_{22} \mathrm{H}_{24} \mathrm{O}_{8} \mathrm{~N}_{2} \cdot \mathrm{HCl}\right)$ with a purity of over $95 \%$ was purchased from Sigma-Aldrich (Munich, Germany) and was used without further purification. Chemical properties of tetracycline hydrochloride are shown in Table $1 . \mathrm{TiO}_{2}$ (P25, Degussa AG, Dusseldorf, Germany) with a specific surface area of $50 \pm 15 \mathrm{~m}^{2} / \mathrm{g}$, primary particle diameter of $21 \mathrm{~nm}$, and a crystal distribution of $80 \%$ anatase and $20 \%$ rutile was purchased from Degussa (Germany). Hydrogen peroxide (30\% w/w) was purchased from R \& M Marketing. All other chemicals used in this study were reagent grade and used without further purification. Analytic reagents were obtained from Merck. Double distilled water was used to prepare the solutions in all experiments. Stock solution of TC and other solutions were prepared in distilled deionized water and diluted as required.

Preparation of the synthetic solution and experimental procedure

TC stock solution $(1,000 \mathrm{mg} / \mathrm{L})$ was prepared weekly using distilled deionized water and stored in dark at $4{ }^{\circ} \mathrm{C}$. All experiments were performed in laboratory scale and batch system and at constant temperature $\left(25^{\circ} \mathrm{C}\right)$ with $250 \mathrm{~mL}$ of $\mathrm{TC}$ solution in a $500-\mathrm{ml}$ reactor. After adjusting the initial $\mathrm{pH}$ with $1 \mathrm{~mol} / \mathrm{L}$ of $\mathrm{H}_{2} \mathrm{SO}_{4}$ or $\mathrm{NaOH}$, solution was mixed with the required amount of $\mathrm{TiO}_{2}$ and magnetically stirred for $30 \mathrm{~min}$ in the dark to ensure complete equilibration of adsorption/desorption of TC onto the $\mathrm{TiO}_{2}$ surface (efficiency $8 \pm 2 \%$ ). After that the UV lamp was turned on. UV irradiation was provided by an $18-\mathrm{W}$ lamp emission at $254 \mathrm{~nm}$ (with intensity of $2,500 \mu \mathrm{W} / \mathrm{cm}^{2}$ ), which was covered with a quartz tube and placed in the middle of the reactor. During photocatalytic experiments, temperature was maintained at $25{ }^{\circ} \mathrm{C}$ by using external water cooling around the reactor. Schematic of the experiment used in this study is shown in Fig. 1. At preselected intervals, $2 \mathrm{~mL}$ aliquots were taken, filtered through a membrane filter $(0.22 \mu \mathrm{m})$, and mixed with $2 \mathrm{~mL}$ methanol to quench the reaction between $\mathrm{OH}^{-}$radicals and the 
Table 1 Chemical properties of tetracycline hydrochloride (Daghrir and Drogui 2013)

\begin{tabular}{lllllll}
\hline Molecule & Formula & Molecular weight $(\mathrm{g} / \mathrm{mol})$ & Solubility $(\mathrm{mol} / \mathrm{L})$ & $\mathrm{pK}_{\mathrm{a} 1}$ & $\mathrm{pK}_{\mathrm{a} 2}$ & $\mathrm{pK}_{\mathrm{a} 3}$ \\
\hline $\mathrm{TC}$ & $\mathrm{C}_{22} \mathrm{H}_{24} \mathrm{O}_{8} \mathrm{~N}_{2} \cdot \mathrm{HCl}$ & 480.9 & 0.041 & $3.2 \pm 0.3$ & $7.78 \pm 0.05$ & $9.6 \pm 0.3$ \\
\hline
\end{tabular}

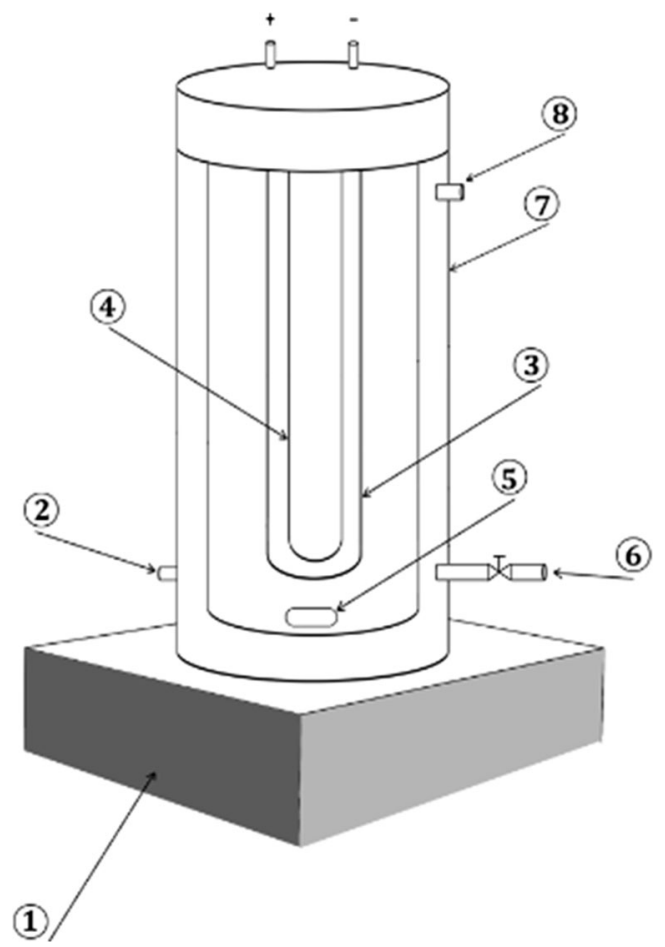

Fig. 1 Schematic of the experiment used in this study; (1) magnetic stirrer, (2) cooling water inlet, (3) quartz tube, (4) UV lamp, (5) stirrer bar, (6) sampling port, (7) outer jacket, and (8) cooling water outlet

remaining TC before analysis. All experiments were performed in duplicate, and values are represented as results with the standard error not exceeding $5 \%$. In aliquots containing $\mathrm{H}_{2} \mathrm{O}_{2}$, aliquot $\mathrm{pH}$ increased immediately after sampling above 10 , in order for $\mathrm{H}_{2} \mathrm{O}_{2}$ degradation and minimized interference in the measurement. TC concentration was measured by a high performance liquid chromatography (HPLC) Shimadzu LC-20 AB pump and Shim-Pack VP-ODS-C18 column $(250 \times 4.6 \mathrm{~mm}, 5 \mathrm{ml})$ with a UV detector (Shimadzu UV-1600 spectrophotometer), flow rate of $1.0 \mathrm{~mL} / \mathrm{min}$, and injection volume of $20 \mu \mathrm{L}$. The mobile-phase acetonitrile/0.01 M oxalic acid solution $(31: 69, \mathrm{v} / \mathrm{v})$ was used as eluent at the wavelength of $360 \mathrm{~nm}$. Standard calibration showed good linearity $\left(R^{2}>0.999\right)$ between the concentrations of TC and the peak area responses. The removal efficiency of TC was expressed using following equation:

Removal efficiency $=\frac{C_{0}-C_{\mathrm{t}}}{C_{0}} \times 100 \%$ where $C_{0}$ and $C_{\mathrm{t}}$ are the concentrations of TC before and after photocatalytic reaction.

\section{Results and discussion}

Degradation of TC and COD removal under different oxidation systems

The results of TC degradation and COD removal under the optimum conditions by different systems at an initial TC concentration of $55 \mathrm{mg} / \mathrm{L}$ are shown in Fig. 2a, b, respectively. After UV irradiation time of $120 \mathrm{~min}$, the degradation of TC reached to $23.8 \%$ with $12.2 \%$ removal of chemical oxygen demand (COD). This could be attributed to this fact that only a limited amount of $\mathrm{HO}^{\circ}$ is formed in the bulk solution in the presence of UV alone, and presumably, the removal efficiency was due to direct photolysis or hydrolysis of antibiotic. This result is similar to the results reported by Kim et al. (2009) and Gao et al. (2012), who studied degradation of amoxicillin, ampicillin, cloxacillin, sulfamethoxazole, and TC antibiotics by UV process. However, in the presence of $\mathrm{TiO}_{2}$, much faster degradation of TC $(83.2 \%)$ and higher mineralization level (50.2\% removal of COD) occurred compared to UV irradiation only. This could be mainly due to the active species produced during the photocatalytic process such as $\mathrm{OH}$ radical, hole and superoxide ion. Some researchers studied the application of $\mathrm{UV} / \mathrm{TiO}_{2}$ for degradation of TC antibiotics and concluded that this process was very efficient. Addamo et al. (2005), who studied the application of this process for TC removal from aqueous solution, reported that TC removal efficiency above $98 \%$ was obtained after $120 \mathrm{~min}$ with $100 \%$ removal of total organic carbon. Reyes et al. (2006), who studied TC photodegradation, reported $100 \%$ of TC degradation after 120 min with higher mineralization level $(90 \%)$. It has been shown by Bu and Zhuang (2013) that photocatalytic processes could be effective to remove more than $80 \%$ of chlortetracycline. These results are similar with those obtained by Palominos et al. (2009), who studied degradation of TC using photocatalysis process. The degradation rate of TC was high $(100 \%)$ with $50 \%$ of mineralization. The addition of $\mathrm{H}_{2} \mathrm{O}_{2}$ to $\mathrm{TiO}_{2}$ suspensions leads to $100 \%$ of TC degradation and $73.7 \%$ of COD removal after 30 and $120 \mathrm{~min}$, respectively. It practices as an electron acceptor from conduction band of semiconductor $\left(\mathrm{TiO}_{2}\right)$ to 

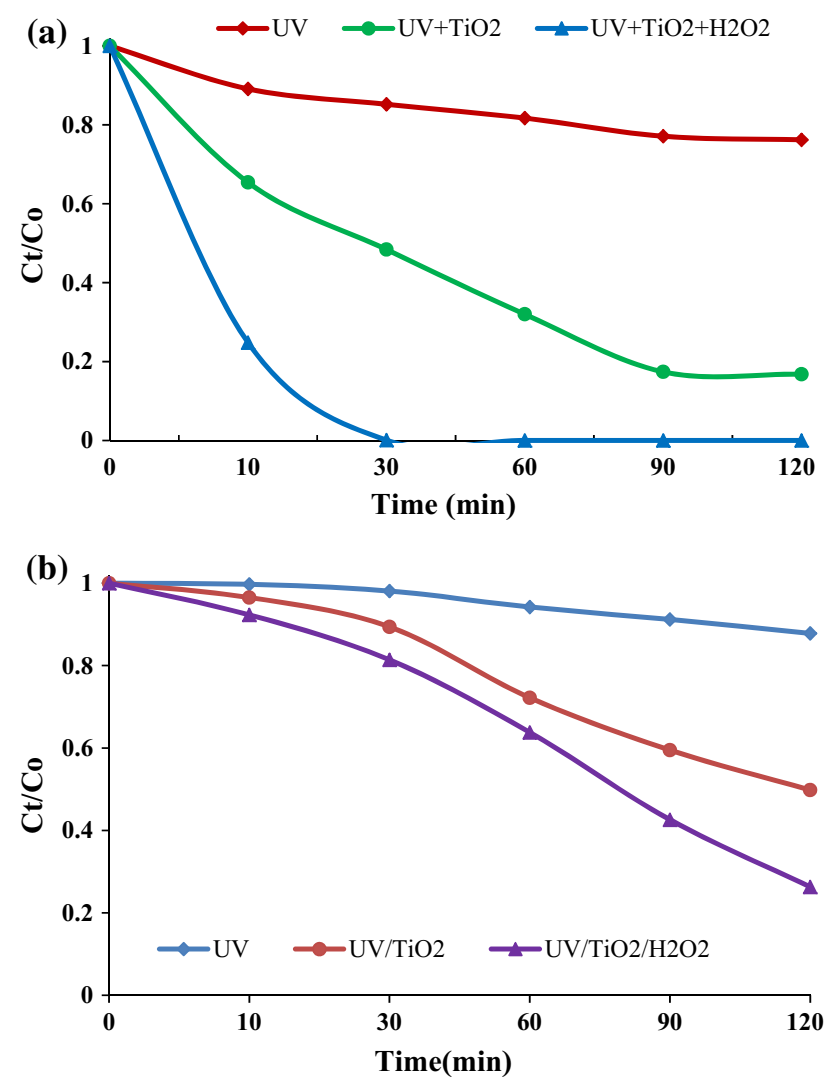

Fig. 2 a Degradation of TC $\mathbf{b}$ removal of COD under different oxidation systems $\quad\left([\mathrm{TC}]=55 \mathrm{mg} / \mathrm{L} ; \quad\left[\mathrm{TiO}_{2}\right]=1 \mathrm{~g} / \mathrm{L}\right.$; $\left[\mathrm{H}_{2} \mathrm{O}_{2}\right]=100 \mathrm{mg} / \mathrm{L} ;[\mathrm{COD}]=90 \mathrm{mg} / \mathrm{L} ; \mathrm{pH}$ 5; lamp power: $18 \mathrm{~W}$ )

produce additional $\mathrm{OH}$ radicals (Elmolla and Chaudhuri 2010b). However, the results of COD removal efficiency suggested that complete mineralization of TC did not occur in the processes but transformed to byproducts, and TC was not completely decomposed to harmless inorganic ions. Therefore, a subsequent treatment is required for complete removal of the TC byproducts. However, there are distinct differences in the COD removal efficiencies of antibiotics using photocatalysis processes. This difference can be partly due to the molecular structure properties of antibiotics. In addition, the different experimental conditions may also lead to the different COD removal efficiencies of antibiotics using photocatalysis processes. It was clear that $\mathrm{UV} / \mathrm{TiO}_{2} / \mathrm{H}_{2} \mathrm{O}_{2}$ process was the best and efficient treatment method for $100 \%$ removal of TC with high mineralization level.

Kinetic study of TC degradation by $\mathrm{UV} / \mathrm{TiO}_{2}$ process

Kinetic study could be useful to investigate and understand the mechanisms of pollutant degradation. Several recent researches have reported that kinetics of the photocatalytic degradation of aqueous pollutants by $\mathrm{TiO}_{2}$ follows the Langmuir-Hinshelwood (L-H) kinetic model (Lazar et al. 2012; Daghrir and Drogui 2013; Subramonian and $\mathrm{Wu}$ 2014). The kinetic model data were evaluated by regression analysis method using Excel software. The L-H kinetic model is expressed as the following equation:

$r=-\frac{\mathrm{d} c}{\mathrm{~d} t} k_{\mathrm{r}} \theta=\frac{k_{r} K C}{1+K C}$

where $r$ is the reaction rate, $k_{r}$ is the reaction rate constant, $K$ is the reactant adsorption constant, $\theta$ is the fraction of the surface of $\mathrm{TiO}_{2}$ covered by $\mathrm{TC}$, and $C$ is the concentration of TC at any time $t$. At low concentrations of TC and weak adsorption ( $\mathrm{KC} \ll 1)$, Eq. (2) can be simplified to a pseudo-first-order kinetic model as following equation:

$r=-\frac{\mathrm{d} c}{\mathrm{~d} t} k_{\mathrm{r}} K C=k_{0} t$

where $k_{0}=k_{r} K$.

The integration of Eq. (3) gives:

$\ln \frac{C_{0}}{C_{\mathrm{t}}}=k_{0} t$

where $C_{0}$ is the initial concentration of $\mathrm{TC}, C_{\mathrm{t}}$ is the concentration of TC at time $t, k_{0}$ is the pseudo-first-order reaction rate constant $\left(\mathrm{min}^{-1}\right)$, and $\mathrm{t}$ is the reaction time (min). The reaction rate constant $(k)$ could be calculated from the slope of a plot of $\ln \left(C_{0} / C_{\mathrm{t}}\right)$ versus $(t)$. The influence of various parameters such as initial TC concentration, initial $\mathrm{TiO}_{2}$ concentration, initial $\mathrm{pH}$, and water matrix on the kinetic of TC degradation was investigated. The values of kinetic rate constants $\left(k_{0}\right)$ related to the various parameters along with their regression coefficients $R^{2}$ are presented in Table 2 . Higher correlation coefficients $R^{2}$ were acquired from the pseudo-first-order kinetic model at various initial TC concentrations. Therefore, the pseudo-first-order kinetic model well described the TC degradation using $\mathrm{UV} / \mathrm{TiO}_{2}$ process. In addition, the higher concentrations of pollutant influence the kinetic degradation (Wang et al. 2009). The photocatalytic degradation rate of TC could be expressed as a function of concentration as the following equation:

$r_{0}=\frac{k_{\mathrm{r}}-K C_{0}}{1+K C_{0}}$

where $r_{0}$ is the initial rate of photocatalytic degradation of TC and $C_{0}$ is the initial concentration of TC. With increasing TC initial concentration from 27 to $103 \mathrm{mg} / \mathrm{L}$, 
Table 2 Influence of various parameters on the kinetic of TC degradation

\begin{tabular}{|c|c|c|c|c|c|}
\hline Parameter & Value & Equation & $k_{0}\left(\min ^{-1}\right)$ & $R^{2}$ & $t_{1 / 2}(\mathrm{~min})^{*}$ \\
\hline \multirow[t]{4}{*}{$\mathrm{TC}$ concentration } & 27 & $\mathrm{y}=0.0249 \mathrm{x}+0.1790$ & $2.49 \times 10^{-2}$ & 0.9962 & 27.8 \\
\hline & 55 & $\mathrm{y}=0.0163 \mathrm{x}+0.2339$ & $1.63 \times 10^{-2}$ & 0.9915 & 42.5 \\
\hline & 74 & $\mathrm{y}=0.0133 \mathrm{x}+0.2159$ & $1.33 \times 10^{-2}$ & 0.9951 & 52.1 \\
\hline & 103 & $\mathrm{y}=0.0110 \mathrm{x}+0.1761$ & $1.10 \times 10^{-2}$ & 0.9963 & 63.0 \\
\hline \multirow[t]{6}{*}{$\mathrm{TiO}_{2}$ concentration } & 0.25 & $\mathrm{y}=0.0038 \mathrm{x}+0.1653$ & $0.38 \times 10^{-2}$ & 0.9501 & 182.4 \\
\hline & 0.5 & $\mathrm{y}=0.0083 \mathrm{x}+0.2028$ & $0.83 \times 10^{-2}$ & 0.9856 & 83.5 \\
\hline & 1 & $\mathrm{y}=0.0163 \mathrm{x}+0.2339$ & $1.63 \times 10^{-2}$ & 0.991 & 42.5 \\
\hline & 1.5 & $\mathrm{y}=0.0153 \mathrm{x}+0.2086$ & $1.53 \times 10^{-2}$ & 0.9956 & 45.3 \\
\hline & 2 & $\mathrm{y}=0.0156 \mathrm{x}+0.2104$ & $1.56 \times 10^{-2}$ & 0.9938 & 44.4 \\
\hline & 5 & $\mathrm{y}=0.0163 \mathrm{x}+0.2339$ & $1.63 \times 10^{-2}$ & 0.9915 & 42.5 \\
\hline \multirow[t]{3}{*}{ Initial $\mathrm{pH}$} & 7 & $\mathrm{y}=0.0084 \mathrm{x}+0.2297$ & $0.87 \times 10^{-2}$ & 0.9953 & 82.5 \\
\hline & 9 & $\mathrm{y}=0.0073 \mathrm{x}+0.1910$ & $0.83 \times 10^{-2}$ & 0.9906 & 94.9 \\
\hline & 11 & $\mathrm{y}=0.0132 \mathrm{x}+0.2534$ & $1.34 \times 10^{-2}$ & 0.9926 & 52.5 \\
\hline \multirow[t]{3}{*}{ Water matrix } & UW & $\mathrm{y}=0.0163 \mathrm{x}+0.2339$ & $1.63 \times 10^{-3}$ & 0.9915 & 42.5 \\
\hline & DW & $\mathrm{y}=0.0227 \mathrm{x}+0.2211$ & $2.27 \times 10^{-3}$ & 0.9935 & 30.5 \\
\hline & SE & $\mathrm{y}=0.0127 \mathrm{x}+0.1822$ & $1.27 \times 10^{-3}$ & 0.9971 & 54.5 \\
\hline \multirow[t]{5}{*}{$\mathrm{H}_{2} \mathrm{O}_{2}$ concentration } & 50 & $\mathrm{y}=0.0303 \mathrm{x}+0.426$ & $3.03 \times 10^{-2}$ & 0.9966 & 22.7 \\
\hline & 75 & $\mathrm{y}=0.05 \mathrm{x}+0.6444$ & $5.0 \times 10^{-2}$ & 0.9993 & 13.8 \\
\hline & 100 & $\mathrm{y}=0.0725 \mathrm{x}+1.0217$ & $7.25 \times 10^{-2}$ & 0.9994 & 9.5 \\
\hline & 150 & $\mathrm{y}=0.0661 \mathrm{x}+0.9232$ & $6.66 \times 10^{-2}$ & 0.9905 & 10.5 \\
\hline & 200 & $\mathrm{y}=0.0442 \mathrm{x}+0.614$ & $4.42 \times 10^{-2}$ & 0.9996 & 15.6 \\
\hline
\end{tabular}

$* t_{1 / 2}=0.693 / \mathrm{k}_{0}$

the degradation rate of $\mathrm{TC}$ increased from 0.6723 to $1.1227 \mathrm{mg} / \mathrm{L} \mathrm{min}$.

Influence of $\mathrm{TiO}_{2}$ concentrations on TC degradation

Figure $3 \mathrm{a}$ shows the removal of $\mathrm{TC}$ at different concentrations of $\mathrm{TiO}_{2}$ at $\mathrm{pH} 5$ and $\mathrm{TC}$ concentration of $55 \mathrm{mg} /$ L. It can be seen that the degradation rate constants increased with increasing $\mathrm{TiO}_{2}$ density at range of $0.25-1 \mathrm{~g} / \mathrm{L}$ and reached a plateau at $\mathrm{TiO}_{2}$ concentration of $1.0 \mathrm{~g} / \mathrm{L}$. The increase of TC degradation with increasing the density of nanosized $\mathrm{TiO}_{2}$ can be due to increased number of active sites, higher formation of $\mathrm{OH}$, and more effective interaction with the TC molecules. However, the degradation rate constants declined slightly at a very high concentration of $1.0 \mathrm{~g} / \mathrm{L}$. This can be due to reductive influence of light, enhancing dispersion of light or sedimentation and agglomeration of $\mathrm{TiO}_{2}$ under larger catalyst loadings (Nosrati et al. 2012; Lazar et al. 2012). Furthermore, at a higher catalyst loading, most of the originally activated $\mathrm{TiO}_{2}$ may be deactivated through collision with ground-state catalysts according to the following equation:
$\mathrm{TiO}_{2}+\mathrm{TiO}_{2}^{\#} \rightarrow \mathrm{TiO}_{2}^{\#}+\mathrm{TiO}_{2}$

where $\mathrm{TiO}_{2}$ has active species adsorbed on its surface and $\mathrm{TiO}_{2}^{\#}$ is the deactivated form of $\mathrm{TiO}_{2}$ (Yang et al. 2008). In addition, accumulation and precipitation of $\mathrm{TiO}_{2}$ under higher catalyst loadings lead to decreasing available catalyst surface for photon absorption and consequently degradation rate decreased. These results are in accordance with the results reported by other researchers who studied the effect of $\mathrm{TiO}_{2}$ nanoparticles on the degradation of other organic pollutants in various AOPs (Mahvi et al. 2009; Dobaradaran et al. 2010; Elmolla and Chaudhuri 2010a; Hoseini et al. 2013a). In another study performed by Rizzo et al. (2009), amoxicillin was completely removed from urban wastewater treatment plant effluent using $\mathrm{TiO}_{2}$ dosage of $0.8 \mathrm{~g} / \mathrm{L}$ after $120 \mathrm{~min}$ of contact time. In another study performed by Michael et al. (2010), the researchers reported $60 \%$ ofloxacin removal from wastewater samples using $\mathrm{TiO}_{2}$ dosage of $3 \mathrm{~g} / \mathrm{L}$. Photoelectrocatalytic process has been applied by Palominos et al. (2009) to oxidize the antibiotic TC in aqueous suspension containing $\mathrm{TiO}_{2}$ or $\mathrm{ZnO}$ under simulated solar light. In this study, the optimal oxidation conditions were $1.5 \mathrm{~g} / \mathrm{L}$ for $\mathrm{TiO}_{2}$ and $1.0 \mathrm{~g} / \mathrm{L}$ for $\mathrm{ZnO}$. In another study conducted by Yang et al. (2008), on 

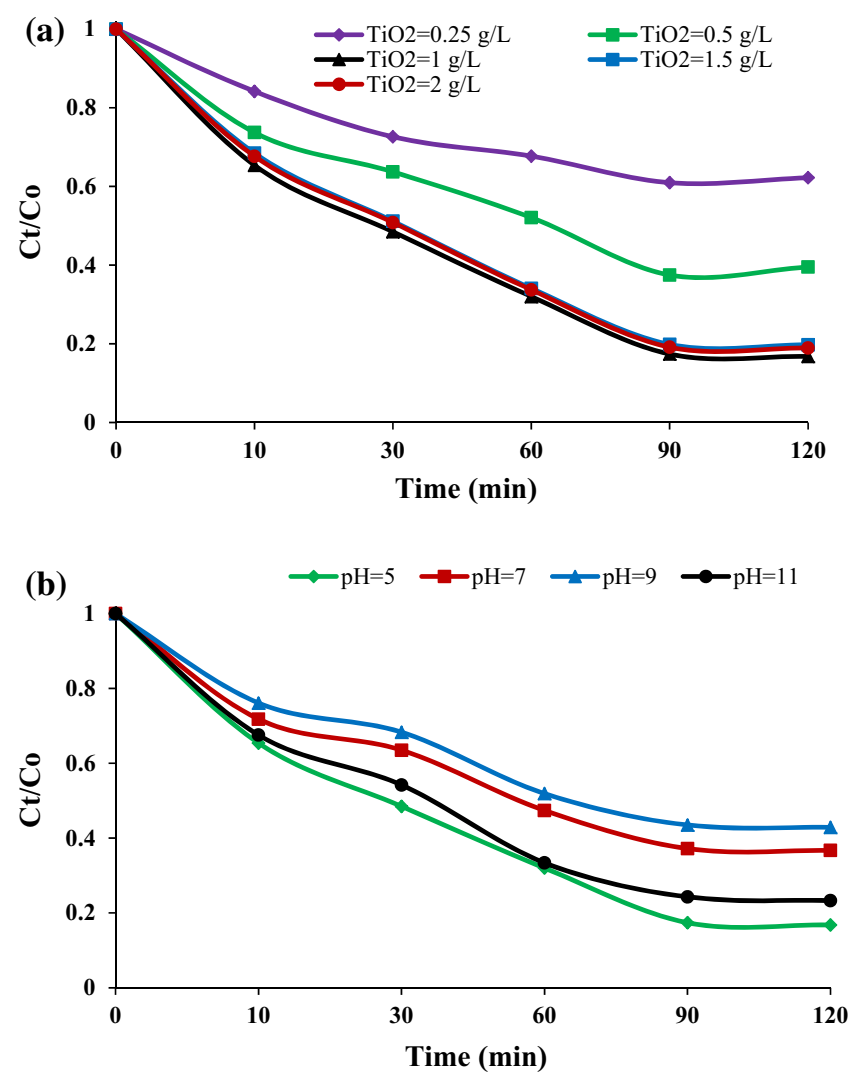

Fig. 3 Influence of a various concentrations of $\mathrm{TiO}_{2}$ b initial pH c initial TC concentration $\mathbf{d}$ water matrix on TC degradation a: $([\mathrm{TC}]=55 \mathrm{mg} / \mathrm{L} ; \mathrm{pH} 5$; lamp power: $18 \mathrm{~W})$; b: $([\mathrm{TC}]=55 \mathrm{mg} / \mathrm{L}$;

degradation of paracetamol in aqueous solutions by $\mathrm{TiO}_{2}$ photocatalysis, the optimal $\mathrm{TiO}_{2}$ loading was $0.8 \mathrm{~g} / \mathrm{L}$. So as the results showed, the optimum concentration of $\mathrm{TiO}_{2}$ catalyst was $1 \mathrm{~g} / \mathrm{L}$.

\section{Influence of initial $\mathrm{pH}$ on $\mathrm{TC}$ degradation}

The initial $\mathrm{pH}$ is one of the most effective parameters in photocatalytic processes which influences on the degradation and adsorption capacity of the target organic compounds by influencing on the surface electrical charge characteristics of photocatalyst and dictates the ionization state of the catalyst surface. In order to evaluate the influence of initial $\mathrm{pH}$ on the removal efficiency, experiments were conducted in various concentrations of TC and $\mathrm{pH}$ in the range of 5-11. As shown in Fig. 3b, the removal efficiencies after 120-min irradiation were 83.4, 63.3, 57.1, and $76.7 \%$ at $\mathrm{pH} 5,7,9$, and 11 , respectively. The results are in accordance with the results reported by Elmolla and Chaudhur (2010a), who studied photocatalytic degradation of amoxicillin, ampicillin, and cloxacillin antibiotics by $\mathrm{UV} / \mathrm{TiO}_{2}$ and $\mathrm{UV} / \mathrm{H}_{2} \mathrm{O}_{2} / \mathrm{TiO}_{2}$ processes. However, it is difficult to interpret the influence of $\mathrm{pH}$ value on
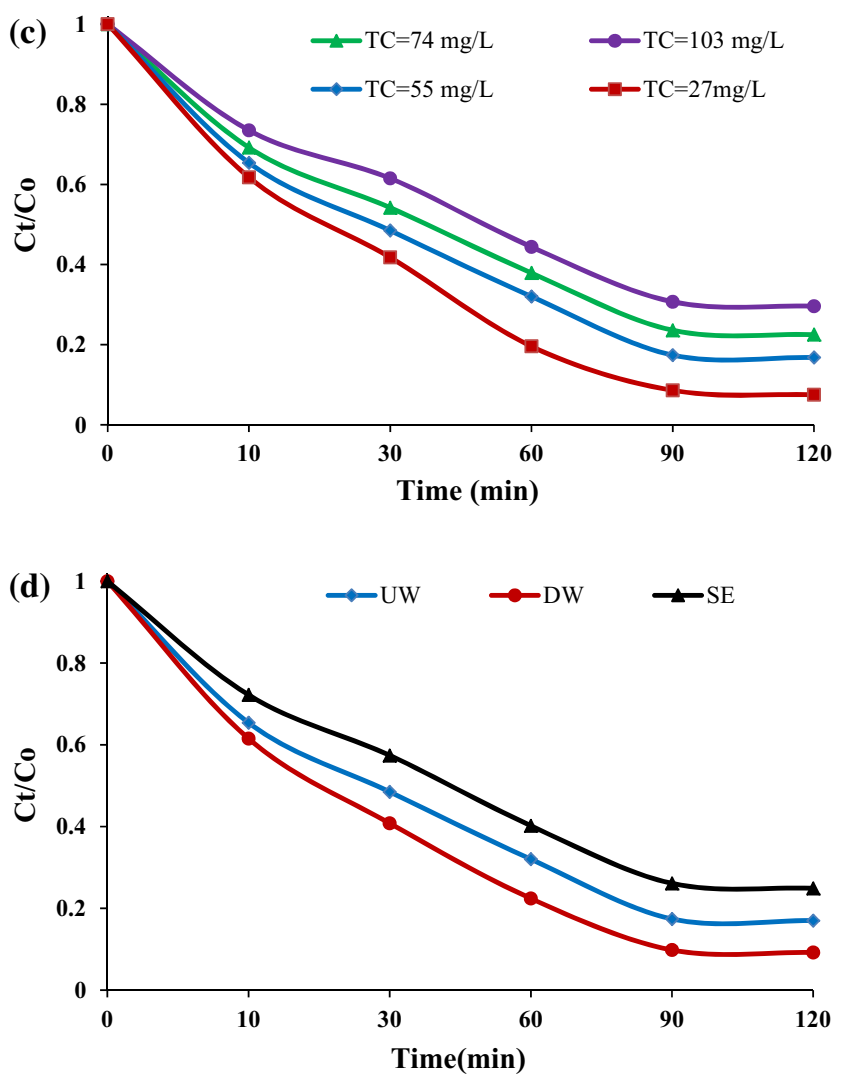

$\left[\mathrm{TiO}_{2}\right]=1 \mathrm{~g} / \mathrm{L}$; lamp power: $\left.18 \mathrm{~W}\right) ; \mathbf{c}:\left(\left[\mathrm{TiO}_{2}\right]=1 \mathrm{~g} / \mathrm{L} ; \mathrm{pH}\right.$; lamp power: $18 \mathrm{~W})$; $\mathbf{d}$ : $\left([\mathrm{TC}]=55 \mathrm{mg} / \mathrm{L} ;\left[\mathrm{TiO}_{2}\right]=1 \mathrm{~g} / \mathrm{L} ; \mathrm{pH} 5\right.$; lamp power: $18 \mathrm{~W}$ )

photodegradation process due to its multiple roles. The $\mathrm{pH}$ value influences on the adsorption and dissociation capacity of compounds, the charge distribution on the catalyst surface, and the oxidation potential of the valence band of catalyst. Firstly, pH changes can influence the adsorption of TC molecules onto the $\mathrm{TiO}_{2}$ surfaces. The $\mathrm{pH}$ point of zero charge (Pzc) of the $\mathrm{TiO}_{2}$ (Degussa P25) is widely reported at $\mathrm{pH} \sim 6.25$. Thus, under $\mathrm{pH}<\mathrm{Pzc}$, the positive charge of the $\mathrm{TiO}_{2}$ surface increases with decreasing $\mathrm{pH}$, and in $\mathrm{pH}<\mathrm{Pzc}$, the negative charge of the $\mathrm{TiO}_{2}$ surface increases with increasing $\mathrm{pH}$ (Ahmed et al. 2010). Secondly, HO radicals can be formed by the reaction between hydroxide ions and positive holes. The positive holes are as the main oxidation species at acidic $\mathrm{pH}$, whereas $\mathrm{OH}$ radicals are as the major species at neutral or alkaline $\mathrm{pH}$ (Liu et al. 2006). Third, the $\mathrm{TiO}_{2}$ particles in the aqueous solutions tend to agglomerate under acidic condition. Therefore, the surface available area of catalyst decreased for TC and photon adsorption (Zhu et al. 2013). On the other hand, it has been found that TC predominantly existed as positively charged molecule at acidic $\mathrm{pH}$ (Wang et al. 2011a, b, c). In acidic $\mathrm{pH}$, both the $\mathrm{TiO}_{2}$ surface and TC molecule are positively charged, and so, the adsorption 
of $\mathrm{TC}$ on the surface of $\mathrm{TiO}_{2}$ decreased at acidic $\mathrm{pH}$. The high removal of antibiotics at acidic $\mathrm{pH}$ compared to that at neutral $\mathrm{pH}$ can be due to hydrolysis of antibiotics (Elmolla and Chaudhuri 2010a). In alkaline, $\mathrm{pH}$ both the $\mathrm{TiO}_{2}$ surface and TC molecule are negatively charged, and thus, repulsive forces between the $\mathrm{TiO}_{2}$ and $\mathrm{TC}$ are developed. Higher removal of TC in alkaline condition may be due to this fact that at alkaline $\mathrm{pH}$ and $\mathrm{OH}$ radicals were easier to be formed by oxidizing more hydroxide ions available on $\mathrm{TiO}_{2}$ surface (Yang et al. 2008).

\section{Influence of initial TC concentration on TC degradation}

Figure $3 \mathrm{c}$ shows the influence of initial TC concentration on the removal efficiency of tetracycline. The results showed that the removal efficiency decreased with the increasing initial TC concentration. Irradiation of TC solution with the initial concentrations of $27,55,74$, and $103 \mathrm{mg} / \mathrm{L}$ for 90 min leads to degradation of $91.4,82.6,76.4$, and $69.3 \%$ of TC, reflecting the low removal efficiency at higher TC concentrations. In order to quantitatively investigate the degradation rate of TC, the experimental data fitted by pseudo-first-order kinetics and the fitting results showed (Table 2) that TC degradation rate constants $(k)$ were calculated to be $2.49 \times 10^{-2}, 1.63 \times 10^{-2}, 1.33 \times 10^{-2}$, and $1.1 \times 10^{-2} \mathrm{~min}^{-1}$ at initial TC concentration of $27,55,74$, and $103 \mathrm{mg} / \mathrm{L}$, respectively. Increase of initial TC concentration leads to the decrease of the TC degradation rate constants. This could be due to the transition from the kinetic control regime at low concentrations to mass transfer limitations at high concentrations. Also at higher concentrations, because of increasing concentrations of intermediate products, hydroxyl radicals become the limiting reactant and so degradation rate constants decreased (Dimitrakopoulou et al. 2012). Moreover, with increasing the initial TC concentration, more TC molecules are adsorbed on the surface of $\mathrm{TiO}_{2}$ nanoparticles. The high amount of adsorbed TC leads to an inhibitive influence on the reaction of TC molecules with photogenerated holes or hydroxyl radicals, due to the lack of any direct contact between them. This could be due to increase of internal optical density, which resulting the solution becomes impervious to UV light (Sin et al. 2011). Furthermore, increasing TC concentration leads to the absorption of light by the TC molecules, and thereby, the photons never reached the photocatalyst surface, and the photocatalytic removal efficiency decreased (Mohammadi et al. 2012). In addition, the reduction in removal efficiency with increasing initial TC concentration could be due to this fact that under the same conditions, the amount of reactive radicals formed was equal in all solutions; therfore, the reaction of TC molecules with radicals becomes more likely at lower
TC concentrations. This can lead to a decrease in the degradation efficiency of TC molecules (Nosrati et al. 2012). These results are similar with results obtained by GomezPacheco et al. (2012) and Jiao et al. (2008b), who studied the degradation of TC using UV irradiation concluded that the TC photolysis rate constants decreased with increase of the initial concentration of TC. In another study, Klauson et al. (2010), who studied amoxicillin (AMX) degradation in the range $10-100 \mathrm{mg} / \mathrm{L}$ with $1 \mathrm{~g} / \mathrm{L}$ Degussa P25 under UV-A, reported that with increasing AMX concentration, degradation rate decreased from 90 to $30 \%$ at 10 and $100 \mathrm{mg} / \mathrm{L}$, respectively.

Influence of water matrix on TC degradation

In order to evaluate the influence of the water matrix on TC degradation, experiments were conducted with ultrapure water (UW), drinking water (DW), and secondary effluent (SE). Chemical characteristics of the water used in this study are listed in Table 3. The influence of water matrix on the removal efficiency of tetracycline is shown in Fig. 3d. The experimental data was fitted by pseudo-firstorder kinetics, with a $k$ value of $1.63 \times 10^{-3}, 2.27 \times 10^{-3}$, and $1.27 \times 10^{-3} \mathrm{~min}^{-1}$ in UW, DW, and SE, respectively (Table 2). The enhancement of removal efficiency of tetracycline in drinking water may be due to the presence of dissolved organic matter, which acts as photosensitizer and can induce either direct degradation of organic compounds via energy transferring or the formation of the reactive species such as radical. This result is similar to the results reported by Lopez-Penalver et al. (2010), and GomezPacheco et al. (2012), who studied the degradation of tetracycline in aqueous solution by ultraviolet irradiation. They concluded that the photodegradation rate was higher in real water (surface and ground water) and lower in wastewater compared to ultrapure water. In another study, Jiao et al. (2008a, b), who studied the influence of humic acid (HA) on photocatalysis of TC and OTC, concluded that the removal efficiency of TC and OTC increased in the presence of $\mathrm{HA}$ with the concentration ranging from 0 to $7.5 \mathrm{mg} / \mathrm{L}$. Also, the addition of dissolved organic carbon (DOC) leads to a higher degradation rate of atrazine compared to the experiment in deionized water (Ziegmann et al. 2006). The lower $k$ value obtained for SE compared to UW may be due to high amount of organic matter, that act as radiation filter, prevent the production of $\mathrm{OH}$ radicals, and so decreased the degradation rate constant (Vione et al. 2006). This was verified by the lower detected transmittance $(T=61.6 \%)$ in SE, and this absorption of UV irradiation substantially decrease the number of photons contacting the TC. In this case, the organic matter present in SE acts as a filter for UV irradiation, decreasing the removal 
efficiency of TC. In addition, hydroxyl radicals can be scavenged by high concentrations of bicarbonates and chlorides present in SE to form the respective radicals, which are lower than the oxidation potential of hydroxyl radicals (Sirtori et al. 2010; Zacharakis et al. 2013). These results are similar with those obtained by Dimitrakopoulou et al. (2012), who studied degradation of amoxicillin by UV-A/ $\mathrm{TiO}_{2}$ photocatalysis. They concluded that degradation rate of amoxicillin in secondary effluent (contains about $8 \mathrm{mg} / \mathrm{L}$ of organic matter, $180 \mathrm{mg} / \mathrm{L}$ bicarbonates and $220 \mathrm{mg} / \mathrm{L}$ chlorides) was lower than ultrapure water (Fig. 4).

Changes of ultraviolet visible (UV-Vis) spectra in the $\mathrm{UV} / \mathrm{TiO}_{2}$ process

In order to investigate the structural changes of TC, the UVVis spectra obtained before and after UV irradiation are shown in Fig. 4. The UV-Vis spectra obtained before irradiation of TC show two major absorption bands at 275 and $360 \mathrm{~nm}$. The absorption of TC in $360 \mathrm{~nm}$ was originated from aromatic rings $\mathrm{B}-\mathrm{D}$, including the developed chromophores (Wang et al. 2011b, c). This absorption band slowly reduced with the irradiation time, which indicated that the fragmentation of phenolic groups attached to aromatic ring B (Wang et al. 2011c; Zhu et al. 2013). The decay of absorbance at $270 \mathrm{~nm}$ band was ascribed to the production of acylamino and hydroxyl groups (Zhu et al. 2013). Furthermore, the reduction of absorption at $360 \mathrm{~nm}$ band associated with a very small absorption in the visible region that can be attributed to the forming of 4a,12a-anhydro-4-oxo-4-dedimethylaminotetracycline according to Fig. 5 (Addamo et al. 2005):

Photodegradation of TC occurs easily and is transformed to many degradation compounds. Side-chain degradation by deamination, desulfurization and dealkylation is typical of most photolysis processes. Photodeamination occurs after the TC exposure to UV irradiation. The removal of volatile dimethylamine needs the loss of only 2 carbon atoms according to the 22 atoms of tetracycline (Addamo et al. 2005). Addamo et al. (2005) reported 4a,12a-anhydro-4-oxo-4-dedimethylaminotetracycline as a major degradation product of TC photolysis by UV, whereas Jeong et al. (2010) proposed products resulting from the loss of $-\mathrm{NH}_{2}$ from the 2-carboxamide group and demethylation from the dimethylamine group at $\mathrm{C}-4$, followed by loss of $-\mathrm{OH}$ at $\mathrm{C}-3$.

Influence of $\mathrm{H}_{2} \mathrm{O}_{2}$ addition to $\mathrm{TiO}_{2}$ suspensions

The addition of $\mathrm{H}_{2} \mathrm{O}_{2}$ to $\mathrm{TiO}_{2}$ suspensions lead to increase the degradation rate of TC, substantially decreasing the
Table 3 Chemical characteristics of the waters used in this study

\begin{tabular}{llll}
\hline Parameters & $\begin{array}{l}\text { Drinking water } \\
(\mathrm{DW})\end{array}$ & $\begin{array}{l}\text { Secondary } \\
\text { effluent }(\mathrm{SE})\end{array}$ & $\begin{array}{l}\text { Ultrapure } \\
\text { water }(\mathrm{UW})\end{array}$ \\
\hline $\mathrm{pH}$ & 7.8 & 8 & 6.6 \\
$\begin{array}{l}\text { Conductivity } \\
(\mu \mathrm{S} / \mathrm{cm})\end{array}$ & 334 & 855 & 0.067 \\
$\mathrm{COD}(\mathrm{mg} / \mathrm{L})$ & $\mathrm{ND}$ & 24 & 0 \\
$\mathrm{HCO}_{3}{ }^{-}(\mathrm{mg} /$ & 63 & 156 & 0 \\
$\mathrm{~L}^{-}$ & & & \\
$\mathrm{Cl}^{-}(\mathrm{mg} / \mathrm{L})$ & 5.8 & 92 & 0 \\
$\mathrm{SO}_{4}{ }^{-}{ }^{-}(\mathrm{mg} / \mathrm{L})$ & 47 & 74 & 0 \\
$\mathrm{NO}_{3}{ }^{-}(\mathrm{mg} / \mathrm{L})$ & $<5$ & 23 & 0 \\
$\mathrm{NO}_{2}{ }^{-}(\mathrm{mg} / \mathrm{L})$ & $<0.1$ & 48 & 0 \\
$\mathrm{Ca}^{2+}$ & 68 & 88 & 0 \\
$\mathrm{Mg}^{2+}$ & 11.5 & 54 & 0 \\
$\mathrm{~T}^{*}(\%)$ & 97.6 & 61.6 & 100 \\
\hline
\end{tabular}

* Transmittance $(\%)$ at $254 \mathrm{~nm}$

time required to $100 \%$ degradation of the TC. It appears that $\mathrm{H}_{2} \mathrm{O}_{2}$ play a dual role in the photocatalytic degradation process. It practices as an electron acceptor from conduction band of semiconductor $\left(\mathrm{TiO}_{2}\right)$ to produce additional $\mathrm{OH}$ radicals according to the following equation:

$\mathrm{H}_{2} \mathrm{O}_{2}+\mathrm{e}^{-} \rightarrow \mathrm{OH}+\mathrm{OH}^{-}$

Moreover, it produces hydroxyl radicals according to the following equation (Elmolla and Chaudhuri 2010b):

$\mathrm{H}_{2} \mathrm{O}_{2}+\mathrm{O}_{2}^{--} \rightarrow \mathrm{OH}^{-}+\mathrm{OH}^{-}+\mathrm{O}_{2}$

The results presented in Table 2 show that by increasing $\mathrm{H}_{2} \mathrm{O}_{2}$ concentration in the range of $50-100 \mathrm{mg} / \mathrm{L}$, degradation rate constants $\left(k_{0}\right)$ increased. This is due to this fact that $\mathrm{H}_{2} \mathrm{O}_{2}$ acts as the limiting reactant at relatively low concentrations. The $100 \%$ degradation of all initial TC concentrations was obtained at $\mathrm{H}_{2} \mathrm{O}_{2}$ concentration of $100 \mathrm{mg} / \mathrm{L}$ after $30 \mathrm{~min}$. With increasing $\mathrm{H}_{2} \mathrm{O}_{2}$ concentration above $100 \mathrm{mg} / \mathrm{L}$, degradation rate constants $\left(k_{0}\right)$ decreased. This could be due to the recombination of $\mathrm{OH}$ radicals and the reaction between them and excess $\mathrm{H}_{2} \mathrm{O}_{2}$ for $\mathrm{H}_{2} \mathrm{O}$ formation according to the following equations (Lopez-Penalver et al. 2010). The influence of various concentrations of $\mathrm{H}_{2} \mathrm{O}_{2}$ on the TC degradation is shown in Fig. 6.

$$
\begin{aligned}
& \mathrm{OH}^{-}+\mathrm{OH}^{-} \rightarrow \mathrm{H}_{2} \mathrm{O}_{2} \\
& \mathrm{OH}^{-}+\mathrm{HO}_{2} \rightarrow \mathrm{H}_{2} \mathrm{O}+\mathrm{O}_{2} \\
& \mathrm{OH}^{-}+\mathrm{H}_{2} \mathrm{O}_{2} \rightarrow \mathrm{H}_{2} \mathrm{O}+\mathrm{HO}_{2} \\
& \mathrm{H}_{2} \mathrm{O}_{2}+\mathrm{h}^{+} \rightarrow \mathrm{H}^{+}+\mathrm{HO}_{2} .
\end{aligned}
$$


Fig. 4 Changes of UV-Vis spectra of $55 \mathrm{mg} / \mathrm{L}$ aqueous solution of tetracycline during photocatalytic process of UV/ $\mathrm{TiO}_{2}$ with irradiation time 0,10 , 30,60 , and $90 \mathrm{~min}$, respectively

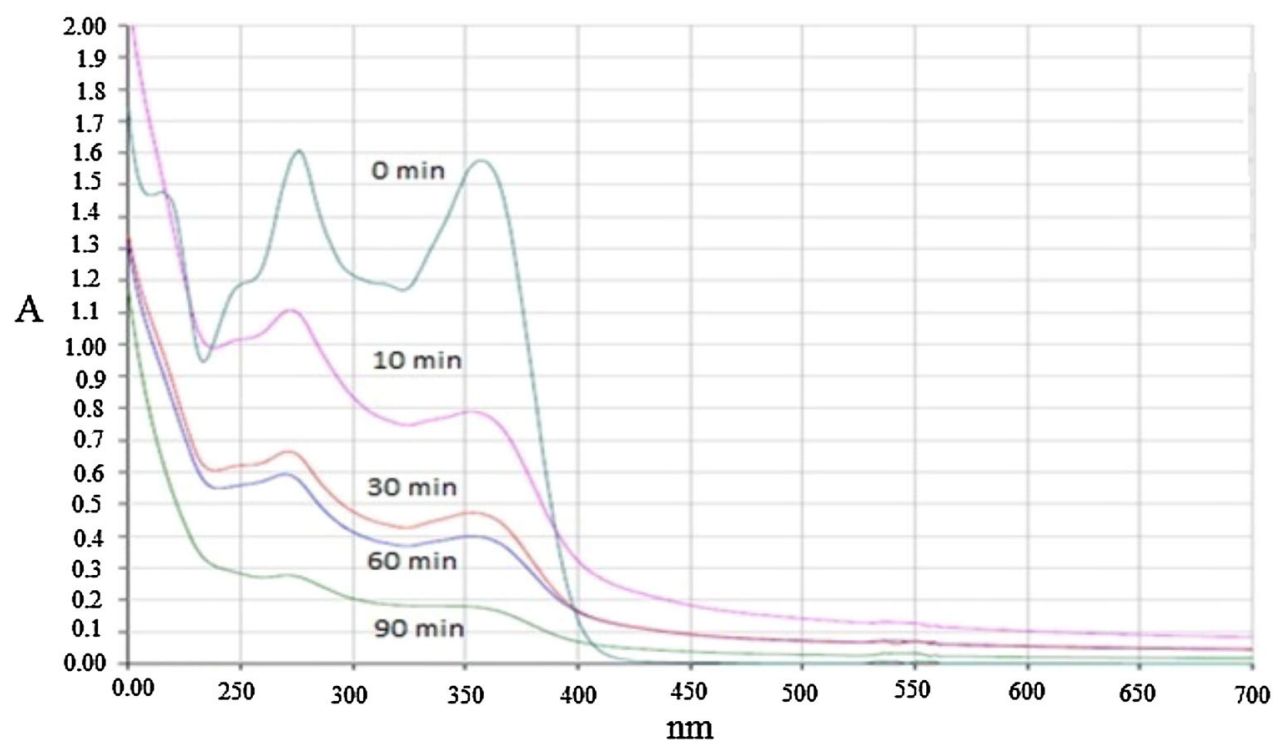<smiles>C[NH+](C)C(N)=O</smiles>

Fig. 5 Photodegradation of TC into 4a, 12a-anhydro-4-oxo-4-dedimethylaminotetracycline

The comparison between current and earlier research on TC photocatalytic degradation using $\mathrm{TiO}_{2}$, the future trends and perspectives

An overview of the works published on TC degradation by photocatalysis processes along with present work is presented in Table 4. As clearly seen in Table 4, UV/TiO process has a good ability for efficient TC degradation but this is not necessarily accompanied with total mineralization. Therefore, a subsequent treatment is required for complete removal of the TC byproducts. However, there are distinct differences in the performance of photocatalysis processes presented in Table 4 . The effectiveness of photocatalytic processes using $\mathrm{TiO}_{2}$ depends on $\mathrm{TiO}_{2}$ concentration, light wavelength and intensity, the initial $\mathrm{pH}$, reaction time, and initial TC concentration. These differences can be partly due to the various operational parameters in each study. Therefore, the different experimental conditions can lead to the different removal efficiencies of antibiotics using photocatalysis processes. It is obvious from Table 4 that among these processes, UV/ $\mathrm{TiO}_{2} / \mathrm{H}_{2} \mathrm{O}_{2}$ process is the best and efficient treatment method for $100 \%$ removal of TC with $74 \%$ chemical oxygen demand removal. By reviewing recent advances in this area and to improve the TC degradation using photocatalysist, it is suggested that future studies should focus on the following topics:

1. Promotion of the photocatalytic activity of $\mathrm{TiO}_{2}$ including the synthesis of mesoporous $\mathrm{TiO}_{2}$ (Joo et al. 2012; Nakata and Fujishima 2012), the use of various $\mathrm{TiO}_{2}$ morphologies (nanowires, nanotubes, and nanospheres; Sun et al. 2012), reduction of the agglomeration in $\mathrm{TiO}_{2}$ powders (Li et al. 2010; Farbod and Khademalrasool 2011) and surface treatments of $\mathrm{TiO}_{2}$ (Monllor-Satoca et al. 2011). Various $\mathrm{TiO}_{2}$ morphologies or surface treatments on $\mathrm{TiO}_{2}$ can be increased the photocatalytic degradation efficiency. 


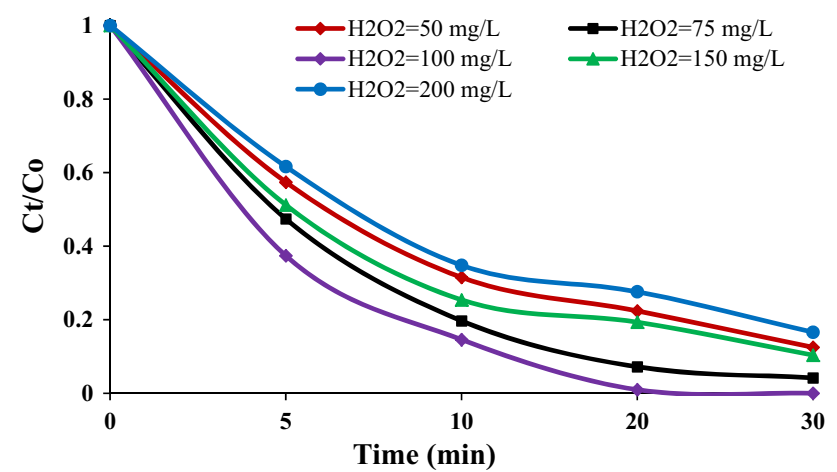

Fig. 6 Influence of various concentrations of $\mathrm{H}_{2} \mathrm{O}_{2}$ on the TC degradation $\left([\mathrm{TC}]=55 \mathrm{mg} / \mathrm{L} ; \quad\left[\mathrm{TiO}_{2}\right]=1 \mathrm{~g} / \mathrm{L} ; \quad \mathrm{pH}=5 ; \quad\right.$ lamp power: $18 \mathrm{~W}$ )

2. Immobilization of $\mathrm{TiO}_{2}$ on suitable support matrices (powder/pellet substrates, soft/thin materials or on rigid/thick substrates) to prevent the post-separation and recovery of the catalyst particles from the reaction mixture in aqueous slurry systems (Shan et al. 2010). However, there are several other advantages including higher surface area, excellent adsorption features and increasing surface hydroxyl groups or decreasing charge recombination in immobilized systems (Esparza et al. 2010; Jin and Dai 2012).
3. Recent innovations in the design of photocalatytic reactors in lab-scale including the use of energyefficient UV/Vis light emitting diodes (LEDs) as light sources (Natarajan et al. 2011) the design of rotating disc-type reactor models (Chang and $\mathrm{Wu}$ 2010), the construction of $\mathrm{TiO}_{2}$-immobilized catalytic beds and post-separation/reuse of $\mathrm{TiO}_{2}$ powder catalysts (Rao et al. 2012). Reasonable designed photocatalytic reactors can reduce energy consumption or can prevent post-separation stages in photocatalytic processes.

4. Doping $\mathrm{TiO}_{2}$ with metals or non-metals can decrease the band gap of the doped catalyst and makes possible the light absorption in the visible region. The improved catalysts seem to be photo-stable in aqueous solution and can be used in photocatalytic water purification (Kuvarega et al. 2011; Barolo et al. 2012).

5. Coupling $\mathrm{TiO}_{2}$ photocatalysis with other treatment process such as electrocatalysis (Daghrir et al. 2012), sonocatalysis/Fenton process (Torres-Palma et al. 2010), biodegradation (Yahiat et al. 2011) and wetland technology (Chen et al. 2011) can be more advantageous; particularly in large-scale treatments. The combination of $\mathrm{TiO}_{2}$ photocatalysis with any of these processes can not only improve the total performance of the degradation but also has the ability of treating great amounts of wastewater in real systems. Also, the

Table 4 Removal of tetracycline using different photocatalysis processes

\begin{tabular}{|c|c|c|c|c|c|c|}
\hline $\begin{array}{l}\mathrm{TC} \\
\text { concentration } \\
(\mathrm{mg} / \mathrm{L})\end{array}$ & Matrix & $\begin{array}{l}\text { Photocatalysis } \\
\text { process }\end{array}$ & $\begin{array}{l}\text { Recommended } \\
\text { operating } \\
\text { conditions }\end{array}$ & Summary of results & Type of $\mathrm{Tio}_{2}$ & References \\
\hline $10-50$ & $\begin{array}{l}\text { Distilled } \\
\text { water }\end{array}$ & $\mathrm{UV} / \mathrm{TiO}_{2}$ & $\begin{array}{c}0.4 \text { and } 1.0 \mathrm{~g} / \mathrm{L} \\
\mathrm{TiO}_{2} ; \mathrm{pH} 6.0\end{array}$ & $\begin{array}{l}\text { More than } 98 \% \text { degradation, } 100 \% \\
\text { of TOC removal after } 120 \mathrm{~min}\end{array}$ & $\begin{array}{l}\mathrm{TiO}_{2} \text { Degussa } \mathrm{P} 25(\mathrm{BET} \\
\text { specific surface } \\
\text { area }=50 \mathrm{~m}^{2} / \mathrm{g}, 80 \% \\
\text { anatase, } 20 \% \text { rutile) } \\
\mathrm{TiO}_{2} \text { Merck }(\mathrm{BET} \\
\text { specific surface } \\
\text { area }=10 \mathrm{~m}^{2} / \mathrm{g}, \\
100 \% \text { anatase) }\end{array}$ & $\begin{array}{l}\text { Addamo } \\
\text { et al. } \\
(2005)\end{array}$ \\
\hline 40 & $\begin{array}{l}\text { Distilled } \\
\text { water }\end{array}$ & $\mathrm{UV} / \mathrm{TiO}_{2}$ & $\begin{array}{l}0.5 \mathrm{~g} / \mathrm{L} \mathrm{TiO}_{2} \\
\mathrm{pH} 6.0\end{array}$ & $\begin{array}{l}100 \% \text { degradation and } 90 \% \text { TOC } \\
\text { removal using UV } 254 \mathrm{~nm} ; 50 \% \\
\text { degradation and } 10 \% \text { TOC removal } \\
\text { using UV } 365 \mathrm{~nm} \text { after } 120 \mathrm{~min}\end{array}$ & $\begin{array}{l}\mathrm{TiO}_{2} \text { Degussa } \mathrm{P} 25 \text { (BET } \\
\text { specific surface area of } \\
50 \mathrm{~m}^{2} / \mathrm{g}, 80 \% \text { anatase } \\
\text { and } 20 \% \text { rutile) }\end{array}$ & $\begin{array}{l}\text { Reyes } \\
\text { et al. } \\
(2006)\end{array}$ \\
\hline 20 & $\begin{array}{l}\text { Distilled } \\
\text { water }\end{array}$ & $\mathrm{UV} / \mathrm{TiO}_{2}$ & $\begin{array}{l}1.5 \mathrm{~g} / \mathrm{L} \mathrm{TiO}_{2} \\
\mathrm{pH} 8.7\end{array}$ & $\begin{array}{l}100 \% \text { degradation and } 50 \% \text { TOC } \\
\text { removal after } 75 \mathrm{~min}\end{array}$ & $\begin{array}{l}\mathrm{TiO}_{2} \text { Degussa } \mathrm{P} 25 \text { (BET } \\
\text { specific surface area of } \\
52 \mathrm{~m}^{2} / \mathrm{g}, 80 \% \text { anatase } \\
\text { and } 20 \% \text { rutile) }\end{array}$ & $\begin{array}{l}\text { Palominos } \\
\text { et al. } \\
\text { (2009) }\end{array}$ \\
\hline \multirow[t]{2}{*}{$27-103$} & \multirow[t]{2}{*}{$\begin{array}{l}\text { Distilled } \\
\text { water }\end{array}$} & $\mathrm{UV} / \mathrm{TiO}_{2}$ & $\begin{array}{l}1.0 \mathrm{~g} / \mathrm{L} \mathrm{TiO} \\
\mathrm{pH}\end{array}$ & $\begin{array}{l}\text { More than } 91.4 \% \text { of degradation after } \\
90 \text { min and } 50 \% \text { COD removal } \\
\text { after } 120 \mathrm{~min}\end{array}$ & \multirow{2}{*}{$\begin{array}{l}\mathrm{TiO}_{2} \text { Degussa } \mathrm{P} 25 \text { (BET } \\
\text { specific surface area of } \\
50 \mathrm{~m}^{2} / \mathrm{g}, 80 \% \text { anatase } \\
\text { and } 20 \% \text { rutile) }\end{array}$} & \multirow[t]{2}{*}{$\begin{array}{c}\text { Present } \\
\text { work }\end{array}$} \\
\hline & & $\begin{array}{l}\mathrm{UV} / \mathrm{TiO}_{2} / \\
\mathrm{H}_{2} \mathrm{O}_{2}\end{array}$ & $\begin{array}{l}1.0 \mathrm{~g} / \mathrm{L} \mathrm{TiO}_{2} \\
\mathrm{pH} \mathrm{5} \\
100 \mathrm{mg} / \mathrm{L} \\
\mathrm{H}_{2} \mathrm{O}_{2}\end{array}$ & $\begin{array}{l}100 \% \text { degradation after } 30 \mathrm{~min} \text { and } \\
74 \% \text { COD removal after } 120 \mathrm{~min}\end{array}$ & & \\
\hline
\end{tabular}


coupling $\mathrm{TiO}_{2}$ photocatalysis as a pre-treatment stage to enhance biodegradability and reduced toxicity with biological post-treatment can be more beneficial.

\section{Conclusion}

Photocatalytic degradation of tetracycline in aqueous solutions was investigated using $\mathrm{TiO}_{2}$ as catalyst to determination of the optimal operation parameters. A slow reduction in tetracycline concentration was observed during the irradiation with UV alone after 120 min irradiation, indicating the influences of directs photolysis or hydrolysis. A more quickly degradation and efficient of tetracycline degradation occurred under UV irradiation in the presence of $\mathrm{TiO}_{2}$. The initial rate of photocatalytic degradation of TC can be well explained by the L-H kinetic model $\left(R^{2}=0.9996\right)$ with a reaction rate constant of $1.4 \mathrm{mg} / \mathrm{L}$ min. $\mathrm{UV} / \mathrm{TiO}_{2}$ process was effective for photodegradation of tetracycline in aqueous phase, especially at low tetracycline concentrations. The obtained degradation rate constants showed that the photodegradation process was $\mathrm{pH}$-dependent. The degradation rate decreased between $\mathrm{pH}$ 5 and 9 , but markedly increased with increasing $\mathrm{pH}$ between 9 and 11. The degradation rate constants also increased with higher $\mathrm{TiO}_{2}$ density and reached a plateau at $\mathrm{TiO}_{2}$ concentration of $1.0 \mathrm{~g} / \mathrm{L}$ and declined slightly at a very much concentration of $1.0 \mathrm{~g} / \mathrm{L}$. The addition of $\mathrm{H}_{2} \mathrm{O}_{2}$ to $\mathrm{TiO}_{2}$ suspension dramatically increased the tetracycline degradation rate and markedly decreased the time required to $100 \%$ degradation of the initial tetracycline concentration. The degradation rate constants also increased with larger $\mathrm{H}_{2} \mathrm{O}_{2}$ concentration and reached a plateau at $\mathrm{H}_{2} \mathrm{O}_{2}$ concentration of $100 \mathrm{mg} / \mathrm{L}$ and decreased at concentrations above $100 \mathrm{mg} / \mathrm{L}$. The tetracycline degradation rate was higher in drinking water than in ultrapure water, which could be due to the presence of dissolved organic matter, which acted as photosensitizer, hence improved indirect degradation of tetracycline through the radical species formation such as $\mathrm{OH}$. The lower rate constant $\left(k_{0}\right)$ value obtained for secondary effluent compared to ultrapure water may be due to much value of organic matter, that act as irradiation filter, inhibit the generation of $\mathrm{OH}$ radicals, and so declined the degradation of tetracycline. Chemical oxygen demand values obtained at the end of the treatment indicated that complete mineralization of tetracycline did not occur but transformed to intermediate products and tetracycline was not completely degraded to harmless mineral ions. Hence, a subsequent treatment is necessary to complete degradation of the tetracycline byproducts. The UV-Vis spectra obtained before and after UV irradiation in the presence of $\mathrm{TiO}_{2}$ indicated the reduction of absorption at $360 \mathrm{~nm}$ band related to a very small absorption in the visible region that can be attributed to the formation of 4a,12a-anhydro-4-oxo-4-dedimethylaminotetracycline.

Acknowledgments The financial and technical support of this research provided by Department of Environmental Health Engineering, School of Public Health, Tehran University of Medical Sciences under Grant No. 20501, gratefully acknowledged.

\section{References}

Addamo M, Augugliaro V, Di Paola A, Garcia-Lopez E, Loddo V, Marci G, Palmisano L (2005) Removal of drugs in aqueous systems by photoassisted degradation. J Appl Electrochem 35(7-8):765-774

Ahmed S, Rasul MG, Martens WN, Brown RJ, Hashib MA (2010) Heterogeneous photocatalytic degradation of phenols in wastewater: a review on current status and developments. Desalination 261(1-2):3-18

Barolo G, Livraghi S, Chiesa M, Paganini MC, Giamello E (2012) Mechanism of the photoactivity under visible light of $\mathrm{N}$-doped titanium dioxide. Charge carriers migration in irradiated $\mathrm{N}-\mathrm{TiO}_{2}$ investigated by electron paramagnetic resonance. J Phys Chem C 116(39):20887-20894

Bu D, Zhuang H (2013) Biotemplated synthesis of high specific surface area copper-doped hollow spherical titania and its photocatalytic research for degradating chlorotetracycline. Appl Surf Sci 265(1):677-685

Chang CY, Wu NL (2010) Process analysis on photocatalyzed dye decomposition for water treatment with $\mathrm{TiO} 2$-coated rotating disk reactor. Ind Eng Chem Res 49(23):12173-12179

Chang PH, Li Z, Jean JS, Jiang WT, Wu Q, Kuo CY, Kraus J (2014) Desorption of tetracycline from montmorillonite by aluminum, calcium, and sodium: an indication of intercalation stability. Int $\mathbf{J}$ Environ Sci Technol 11:633-644

Chen KC, Wang YH, Lu YC (2011) Treatment of polluted water for reclamation using photocatalysis and constructed wetlands. Catal Today 175(1):276-282

Daghrir R, Drogui P (2013) Tetracycline antibiotics in the environment: a review. Environ Chem Lett 11(3):209-227

Daghrir R, Drogui P, Ka I, Khakani MA (2012) Photoelectrocatalytic degradation of chlortetracycline using $\mathrm{Ti} / \mathrm{TiO}_{2}$ nanostructured 
electrodes deposited by means of a pulsed laser deposition process. J Hazard Mater 199(1):15-24

Deng J, Shao Y, Gao N, Deng Y, Tan C, Zhou S (2014) Zero-valent iron/persulfate $\left(\mathrm{Fe}_{0} / \mathrm{PS}\right)$ oxidation acetaminophen in water. Int $\mathrm{J}$ Environ Sci Technol 11:881-890

Dimitrakopoulou D, Rethemiotaki I, Frontistis Z, Xekoukoulotakis NP, Venieri D, Mantzavinos D (2012) Degradation, mineralization and antibiotic inactivation of amoxicillin by $\mathrm{UV}-\mathrm{A} / \mathrm{TiO}_{2}$ photocatalysis. J Environ Manag 98(1):168-174

Dobaradaran S, Nabizadeh R, Mahvi A, Mesdaghinia A, Naddafi K, Yunesian M, Rastkari N, Nazmara S (2010) Survey on degradation rates of trichloroethylene in aqueous solutions by ultrasound. Iran J Environ Health Sci Eng 7(4):307-312

Elmolla ES, Chaudhuri M (2010a) Comparison of different advanced oxidation processes for treatment of antibiotic aqueous solution. Desalination 256(1):43-47

Elmolla ES, Chaudhuri M (2010b) Photocatalytic degradation of amoxicillin, ampicillin and cloxacillin antibiotics in aqueous solution using $\mathrm{UV} / \mathrm{TiO}_{2}$ and $\mathrm{UV} / \mathrm{H}_{2} \mathrm{O}_{2} / \mathrm{TiO}_{2}$ photocatalysis. Desalination 252(1):46-52

Esparza P, Borges ME, Diaz L, Alvarez-Galvan MC, Fierro JLG (2010) Photodegradation of dye pollutants using new nanostructured titania supported on volcanic ashes. Appl Catal A 388(1):7-14

Farbod M, Khademalrasool M (2011) Synthesis of $\mathrm{TiO}_{2}$ nanoparticles by a combined sol-gel ball milling method and investigation of nanoparticle size influence on their photocatalytic activities. Powder Technol 214(3):344-348

Gao YQ, Gao NY, Deng Y, Yang YQ, Ma Y (2012) Ultraviolet (UV) light-activated persulfate oxidation of sulfamethazine in water. Chem Eng J 195(1):248-253

Gomez-Pacheco C, Sanchez-Polo M, Rivera-Utrilla J, Lopez-Penalver J (2012) Tetracycline degradation in aqueous phase by ultraviolet radiation. Chem Eng J 187(1):89-95

Homem V, Santos L (2011) Degradation and removal methods of antibiotics from aqueous matrices-a review. J Environ Manag 92(10):2304-2347

Hoseini M, nabizadeh R, nazmara SH, Safari GH (2013a) Influence of under pressure dissolved oxygen on trichloroethylene degradation by the $\mathrm{H}_{2} \mathrm{O}_{2} / \mathrm{TiO}_{2}$ process. J Environ Health Sci Eng 11(38):2-6

Hoseini M, Safari GH, Kamani H, Jaafari J, Ghanbarain M, Mhvi AH (2013b) Sonocatalytic degradation of tetracycline antibiotic in aqueous solution by sonocatalysis. Toxicol Environ Chem 95(10): 1680-1689

Ifelebuegu AO, Onubogu J, Joyce E, Mason T (2014) Sonochemical degradation of endocrine disrupting chemicals 17b-estradiol and 17 a-ethinylestradiol in water and wastewater. Int J Environ Sci Technol 11:1-8

Jeong J, Song W, Cooper WJ, Jung J, Greaves J (2010) Degradation of tetracycline antibiotics: mechanisms and kinetic studies for advanced oxidation/reduction processes. Chemosphere 78(5):533-540

Jiang WT, Chang PH, Wang YS, Tsai Y, Jean JS, Li Z (2014) Sorption and desorption of tetracycline on layered manganese dioxide birnessite. Int J Environ Sci Technol. doi:10.1007/ s13762-014-0547-6
Jiao S, Zheng S, Yin D, Wang L, Chen L (2008a) Aqueous oxytetracycline degradation and the toxicity change of degradation compounds in photoirradiation process. J Environ Sci 20(7):806-813

Jiao S, Zheng S, Yin D, Wang L, Chen L (2008b) Aqueous photolysis of tetracycline and toxicity of photolytic products to luminescent bacteria. Chemosphere 73(3):377-382

Jin L, Dai B (2012) $\mathrm{TiO}_{2}$ activation using acid-treated vermiculite as a support: characteristics and photoreactivity. Appl Surf Sci 258(8):3386-3392

Joo JB, Zhang Q, Dahl M, Lee I, Goebl J, Zaera F, Yin YD (2012) Control of the nanoscale crystallinity in mesoporous $\mathrm{TiO}_{2}$ shells for enhanced photocatalytic activity. Energy Environ Sci 5(4):6321-6327

Khan MH, Bae H, Jung JY (2010) Tetracycline degradation by ozonation in the aqueous phase: proposed degradation intermediates and pathway. J Hazard Mater 181(1):659-665

Kim I, Tanaka H (2009) Photodegradation characteristics of PPCPS in water with UV treatment. Environ Int 35(1):793-802

Kim I, Yamashita N, Tanaka H (2009) Performance of UV and UV/ $\mathrm{H}_{2} \mathrm{O}_{2}$ processes for the removal of pharmaceuticals detected in secondary effluent of a sewage treatment plant in Japan. J Hazard Mater 166(2):1134-1140

Klauson D, Babkina J, Stepanova K, Krichevskaya M, Preis S (2010) Aqueous photocatalytic oxidation of amoxicillin. Catal Today 151(1):39-45

Kummerer K (2009) Antibiotics in the aquatic environment-a review-part I. Chemosphere 75(4):417-434

Kuvarega AT, Krause RWM, Mamba BB (2011) Nitrogen/palladiumcodoped $\mathrm{TiO}_{2}$ for efficient visible light photocatalytic dye degradation. J Phys Chem C 115(45):22110-22120

Lazar MA, Varghese S, Nair SS (2012) Photocatalytic water treatment by titanium dioxide: recent updates. Catalysts 2(4):572-601

Li G, Lv L, Fan HT, Ma JY, Li YQ, Wan Y, Zhao XS (2010) Influence of the agglomeration of $\mathrm{TiO}_{2}$ nanoparticles on their photocatalytic performance in the aqueous phase. $\mathrm{J}$ Colloid Interface Sci 348(2):342-347

Lin CC, Lee LT, Hsu LJ (2014) Degradation of polyvinyl alcohol in aqueous solutions using UV-365 $\mathrm{nm} / \mathrm{S}_{2} \mathrm{O}_{8}^{-2}$ process. Int $\mathrm{J}$ Environ Sci Technol 11:831-838

Lindsey ME, Meyer M, Thurman E (2011) Analysis of trace levels of sulfonamide and tetracycline antimicrobials in groundwater and surface water using solid-phase extraction and liquid chromatography/mass spectrometry. Anal Chem 73(19):4640-4646

Liu CC, Hsieh YH, Lai PF, Li CH, Kao CL (2006) Photodegradation treatment of azo dye wastewater by $\mathrm{UV} / \mathrm{TiO}_{2}$ process. Dyes Pigments 68(2):191-195

Liu H, Yang Y, Kang J, Fan M, Qu J (2012) Removal of tetracycline from water by Fe-Mn binary oxide. J Environ Sci 24(2):242-247

Lopez-Penalver J, Sanchez-Polo JM, Gómez-Pacheco CV, RiveraUtrilla J (2010) Photodegradation of tetracyclines in aqueous solution by using $\mathrm{UV}$ and $\mathrm{UV} / \mathrm{H}_{2} \mathrm{O}_{2}$ oxidation processes. J Chem Technol Biotechnol 85(10):1325-1333

Mahvi AH (2009) Application of ultrasonic technology for water and wastewater treatment. Iran J Public Health 38(2):1-17 
Mahvi AH, Maleki A (2010) Photosonochemical degradation of phenol in water. Desalin Water Treat 20(1-3):197-202

Mahvi AH, Maleki A, Rezaee R, Safari M (2009) Reduction of humic substances in water by application of ultrasound waves and ultraviolet irradiation. Iran $J$ Environ Health Sci Eng 6(4):233-240

Maroga Mboula V, Hequet V, Gru Y, Colin R, Andres Y (2012) Assessment of the efficiency of photocatalysis on tetracycline biodegradation. J Hazard Mater 209(1):355-364

Michael I, Hapeshi E, Michael C, Fatta-Kassinos D (2010) Solar Fenton and solar $\mathrm{TiO}_{2}$ catalytic treatment of ofloxacin in secondary treated effluents: evaluation of operational and kinetic parameters. Water Res 44(18):5450-5462

Mohammadi R, Massoumi B, Rabani M (2012) Photocatalytic decomposition of amoxicillin trihydrate antibiotic in aqueous solutions under UV irradiation using $\mathrm{Sn} / \mathrm{TiO}_{2}$ nanoparticles. Int J Photoenergy 2012 1:1-11

Monllor-Satoca D, Lana-Villarreal T, Gomez R (2011) Influence of surface fluorination on the electrochemical and photoelectrocatalytic properties of nanoporous titanium dioxide electrodes. Langmuir 27(24):15312-15321

Nakata K, Fujishima A (2012) $\mathrm{TiO}_{2}$ photocatalysis: design and applications. J Photochem Photobiol C 13(3):169-189

Natarajan TS, Thomas M, Natarajan K, Bajaj HC, Tayade RJ (2011) Study on UV-LED/TiO2 process for degradation of rhodamine $\mathrm{B}$ dye. Chem Eng J 169(1-3):126-134

Nosrati R, Olad A, Maramifar R (2012) Degradation of ampicillin antibiotic in aqueous solution by $\mathrm{ZnO}$ /polyaniline nanocomposite as photocatalyst under sunlight irradiation. Environ Sci Pollut R 19(6):2291-2299

Palominos RA, Mondaca MA, Giraldo A, Penuela G, Perez-Moya M, Mansilla HD (2009) Photocatalytic oxidation of the antibiotic tetracycline on $\mathrm{TiO}_{2}$ and $\mathrm{ZnO}$ suspensions. Catal Today 144(1):100-105

Rao NN, Chaturvedi V, Puma GL (2012) Novel pebble bed photocatalytic reactor for solar treatment of textile wastewater. Chem Eng J 184(1):90-97

Reyes C, Fernandez J, Freer J, Mondaca MA, Zaror C, Malato S, Mansilla H (2006) Degradation and inactivation of tetracycline by $\mathrm{TIO}_{2}$ photocatalysis. J Photochem Photobiol A 184(1):141-146

Rizzo L, Meric S, Guida M, Kassinos D, Belgiorno V (2009) Heterogenous photocatalytic degradation kinetics and detoxification of an urban wastewater treatment plant effluent contaminated with pharmaceuticals. Water Res 43(16):4070-4078

Shan AY, Ghazi TIM, Rashid SA (2010) Immobilisation of titanium dioxide onto supporting materials in heterogeneous photocatalysis: a review. Appl Catal A 389(1-2):1-8

Sin JC, Lam SM, Mohamed AR, Lee KT (2011) Degrading endocrine disrupting chemicals from wastewater by $\mathrm{TiO}_{2}$. Int $\mathrm{J}$ Photoenergy 2012 1:1-23
Sirtori C, Agüera A, Gernjak W, Malato S (2010) Influence of watermatrix composition on Trimethoprim solar photodegradation kinetics and pathways. Water Res 44(9):2735-2744

Subramonian W, Wu TY (2014) Effect of enhancers and inhibitors on photocatalytic sunlight treatment of methylene blue. Water Air Soil Pollut 225:1922

Sun X, Zhang J, Zhang G, Pan X, Huang T (2012) Preparation and characteristics of $\mathrm{TiO} 2$ nanotube catalysts used in hybrid photocatalysis/membrane process. Catal Commun 18(1):76-80

Tay KS, Rahman NA, Bin Abas MR (2013) Chemical oxidation of N, $\mathrm{N}$-diethyl-m-toluamide by sulfate radical-based oxidation: kinetics and mechanism of degradation. Int J Environ Sci Technol 10:103-112

Torres-Palma RA, Nieto JI, Combet E, Petrier C, Pulgarin C (2010) An innovative ultrasound, $\mathrm{Fe}^{2+}$ and $\mathrm{TiO}_{2}$ photoassisted process for bisphenol A mineralization. Water Res 44(7):2245-2252

Vione D, Falletti G, Maurino V, Minero C, Pelizzetti E, Malandrino M, Ajassa R, Olariu RI, Arsene C (2006) Sources and sinks of hydroxyl radicals upon irradiation of natural water samples. Environ Sci Technol 40(12):3775-3781

Wammer KH, Slattery MT, Stemig AM, Ditty JL (2011) Tetracycline photolysis in natural waters: loss of antibacterial activity. Chemosphere 85(9):1505-1510

Wang N, Li X, Wang Y, Quan X, Chen G (2009) Evaluation of bias potential enhanced photocatalytic degradation of 4-chlorophenol with $\mathrm{TiO}_{2}$ nanotube fabricated by anodic oxidation method. Chem Eng J 146(1):30-35

Wang P, Yap PS, Lim TT (2011a) C-N-S tridoped TiO2 for photocatalytic degradation of tetracycline under visible-light irradiation. Appl Catal A 399(1):252-261

Wang Y, Zhang H, Chen L (2011b) Ultrasound enhanced catalytic ozonation of tetracycline in a rectangular air-lift reactor. Catal Today 175(1):283-292

Wang Y, Zhang H, Zhang J, Lu C, Huang Q, Wu J, Liu F (2011c) Degradation of tetracycline in aqueous media by ozonation in an internal loop-lift reactor. J Hazard Mater 192(1):35-43

Yahiat S, Fourcade F, Brosillon S, Amrane A (2011) Removal of antibiotics by an integrated process coupling photocatalysis and biological treatment-case of tetracycline and tylosin. Int Biodeterior Biodegrad 65(7):997-1003

Yang L, Yu LE, Ray MB (2008) Degradation of paracetamol in aqueous solutions by $\mathrm{TiO}_{2}$ photocatalysis. Water Res 42(13):3480-3488

Zacharakis A, Chatzisymeon E, Binas V, Frontistis Z, Venieri D, Mantzavinos D (2013) Solar photocatalytic degradation of bisphenol $\mathrm{A}$ on immobilized $\mathrm{ZnO}$ or $\mathrm{TiO}_{2}$. Int $\mathrm{J}$ Photoenergy $1: 1-9$

Zgajnar Gotvajn A, Bistan M, Tisler T, Englande AJ, Zagorc-Koncan J (2013) The relevance of bisphenol A adsorption during Fenton's oxidation. Int J Environ Sci Technol 10:1141-1148 
Zhu XD, Wang YJ, Sun RJ, Zhou DM (2013) Photocatalytic degradation of tetracycline in aqueous solution by nanosized $\mathrm{TiO}_{2}$. Chemosphere 92(8):925-932
Ziegmann M, Doll T, Frimmel FH (2006) Matrix influences on the photocatalytical degradation of dichloroacetic acid and atrazine in water. Acta Hydrochim Hydrobiol 34(1-2):146-154 